\title{
MANAJEMEN PELAYANAN BAGI PESERTA BPJS KESEHATAN DI RSUD SYECH YUSUF KABUPATEN GOWA
}

\author{
RAHMAH NUJANNAH ${ }^{1}$,ANDI NURAENI AKSA ${ }^{2}$,MUHAMMMAD IDRIS ${ }^{3}$
}

1) Jurusan Ilmu Administrasi Negara Fisipol Unismuh Makassar
2) Jurusan Ilmu Administrasi Negara Fisipol Unismuh Makassar
3) Jurusan Ilmu Administrasi Negara Fisipol Unismuh Makassar

\begin{abstract}
ABSTRACK
The research aim was to know the plan, application and supervision of serving for the health BPJS member in Syech Yusuf hospital in Gowa regency. The research kind was the descriptive qualitative. The Informan were 8 people. The data source was the primer data and secunder data. The data collecting technique used the observation, documentation and interview for instrument. The research result showed that still there were the patient who came and did not get the quick service, sometimes they have to be in line for hours if would like of the employs were often came late. The patient would like to get the good service but they got the otherwise.
\end{abstract}

keywords: management, service, healthy BPJS

\begin{abstract}
ABSTRAK
Tujuan penelitian adalah untuk mengetahui Perencanaan, Pelaksanaan dan Pengawasan pelayanan bagi peserta BPJS kesehatan di RSUD Syech Yusuf Kabupaten Gowa. Jenis penelitian adalah deskriptif kualitatif. Informan berjumlah delapan orang. Data bersumber dari data primer dan data sekunder. Tehnik pengumpulan data menggunakan instrumen berupa observasi, dokumentasi dan wawancara. Hasil penelitian menunjukkan bahwa masih banyak pasien yang datang tidak mendapat pelayanan dengan cepat, kadang antri berjam-jam bila ingin berobat. Hal yang lain dapat kita lihat bahwa sebagian pegawainya sering datang terlambat. Pasien ingin mendapat pelayanan yang baik akan tetapi pelayanan yang didapatkan tidak sesuai dengan yang diharapkan.
\end{abstract}

kata kunci: manajemen, pelayanan,BPJS kesehatan 


\section{PENDAHULUAN}

Penyelenggaraan pelayanan publik merupakan upaya negara untuk memenuhi kebutuhan dasar dan hak-hak sipil setiap warga negara atas barang, jasa dan pelayanan administrasi yang di sediakan oleh penyelenggara pelayanan publik di Indonesia yang mengamanatkan kepada negara agar memenuhi kebutuhan dasar setiap warganya demi kesejahteraannya sehingga efektivitas suatu sistem pemerintahan sangat di tentukan oleh baik buruknya penyelenggaraan pelayanan publik. Penyelenggara pelayanan publik di Indonesia adalah semua organ negara seperti Pemerintah Pusat, Pemerintah Daerah.

Era reformasi kelihatannya tidak membawa perubahan signifikan terhadap pelayanan publik. Masyarakat sebagai konsumen sebagai aktivis birokrasi pemerintah masih mengeluhkan banyak hal, seperti masih kuatnya dugaan $\mathrm{KKN}$, masih bertele-telenya jalur birokrasi dan juga masih lemahnya motivasi Pegawai Negeri Sipil untuk berubah. Pelayanan publik yang diorganisasikan oleh birokrasi pun masih terkesan tidak berubah, seperti angkutan yang masih berdesakdesakan, listrik yang masih saja bergilir pemadamannya, adanya pungutan liar ketika pembuatan KTP. Pelayanan adalah kunci keberhasilan dalam berbagai usaha atau kegiatan yang bersifat jasa.

Setelah pelanggan puas, timbal balik yang diharapkan perusahaan sebagai penyedia jasa adalah kesediaan dari pelanggan tersebut untuk berminat menyampaikan kesan baik yang diterima kepada pihak lain. Sektor rumah sakit akhir -akhir ini telah mengalami perubahan yang sangat drastis dengan ditandai semakin ketatnya persaingan antara pengelola yang berada dalam sektor industri rumah sakit untuk memperebutkan pasar yang sama. Persaingan yang semakin ketat antar rumah sakit, baik milik pemerintah maupun dengan rumah sakit swasta (yayasan) maupun milik pribadi. Indonesia telah menjalankan beberapa program jaminan sosial. Berbagai program tersebut diatas baru mencakup sebagian kecil masyarakat. Sebagian besar rakyat belum memperoleh perlindungan yang memadai. 
Undang-Undang Nomor 24

Tahun 2011 tentang Badan

Penyelenggara Jaminan Sosial bahwa sistem jaminan sosial nasional merupakan program negara yang bertujuan memberikan kepastian perlindungan dan kesejahteraan sosial bagi seluruh rakyat Indonesia.

Manajemen menurut Ismail Solihin (2010:4) menjelaskan bahwa Manajemen adalah Proses perencanaan, pengorganisasian, kepemimpinan dan pengendalian dari berbagai sumber organisasi untuk mencapai tujuan secara efektif dan efesien.

Menurut Anton Mulyono Aziz

dan Maya Irjayanti (2014:5) Manajemen adalah Seni, manajemen meliputi kemampuan untuk melihat totalitas dari bagian yang terpisah-pisah serta kemampuan untuk menciptakan gambaran tentang suatu visi.

Menurut Ulber Silalahi (2011:7) Manajemen adalah Sebagai proses perencanaan, pengorganisasian, pengaturan sumberdaya, pengomunikasian, pemimpinan, pemotivasian,dan pengendalian pelaksanaan t6ugas-tugas dan pengunaan sumber-sumber untuk mencapai tujuan organisasional secara efektif dan secara efesien.
Menurut Irham Fahmi (2011:2) Manajemen adalah Suatu ilmu yang mempelajari secara komprehensif tentang bagaimana mengarahkan dan mengelola orang-orang dengan berbagai latar belakang yang berbedabeda dengan tujuan untuk mencapai tujuan yang diinginkan.

Menurut Lilis Sulastri (2014:14) Manajemen adalah Suatu seni mengatur yang melibatkan proses, cara, dan tindakan tertentu, seperti perencanaan, pengorganisasian, pengarahan dan pengendalian atau pengawasan, yang dilakukan untuk menentukan dan mencapai tujuan secara efesien dan efektif dengan dan melalui orang lain. Dari kelima definisi diatas penulis mengambil kesimpulan bahwa manajemen adalah suatu proses perencanaan, pengorganisasian, pengendalian, pengawasan secara efektif dan efesien untuk mencapai tujuan bersama.

Menurut G.Terry (2010:9), fungsi manajemen dapat dibagi menjadi tiga bagian, yakni planning (perencanaan), actuating (pelaksanaan) dan controlling (pengawasan) : a.Planning (perencanaan) ialah penetapan pekerjaan yang harus 
dilaksanakan oleh kelompok untuk mencapai tujuan yang digariskan. Planning mencakup kegiatan pengambilan keputusan, karena termasuk dalam pemilihan alternatif-alternatif keputusan. Diperlukan kemampuan untuk mengadakan visualisasi dan melihat ke depan guna merumuskan suatu pola dari himpunan tindakan untuk masa mendatang. b.Actuating (Pelaksanaan) merupakan usaha menggerakkan anggota-anggota kelompok sedemikian rupa, hingga mereka berkeinginan dan berusaha untuk mencapai tujuan yang telah direncanakan bersama. c.Controlling (pengawasan) adalah penemuan dan penerapan cara dan alat untuk menjamin bahwa rencana telah dilaksanakan sesuai dengan rencana yang telah ditetapkan.

Menurut A.S. Moenir (2002:26) mendefinisikan "pelayanan sebagai kegiatan yang dilakukan oleh seseorang atau sekelompok orang dengan landasan tertentu dimana tingkat pemuasannya hanya dapat dirasakan oleh orang yang melayani atau dilayani, tergantung kepada kemampuan penyedia jasa dalam memenuhi harapan pengguna.
Selanjutnya menurut A.S. Moenir (2002:16) menyatakan bahwa proses pemenuhan kebutuhan melalui aktivitas orang lain yang langsung inilah yang dinamakan pelayanan. Jadi dapat dikatakan pelayanan adalah kegiatan yang bertujuan untukmembantu menyiapkan atau mengurus apa yang diperlukan orang lain. Dari definifi tersebut dapat dimaknai bahwa pelayanan adalah aktivitas yang dapat dirasakan melalui hubungan antara penerima dan pemberi pelayanan yang menggunakan peralatan berupa organisasi atau lembaga perusahaan.

Pelayanan publik dalam ( Keputusan MENPAN Nomor 63/2003) "segala bentuk kegiatan pelayanan yang di laksanakan oleh instansi pemerintah di pusat,di daerah dan di lakukan oleh badan usaha milik negara atau daerah dalam bentuk barang atau jasa dalam rangka pemenuhan kebutuhan masyarakat maupun dalam rangka pelaksanaan kebutuhan peraturan perundang-undangan".

Pengertian pelayanan publik menurut Ibrahim Amin (2008) adalah segala bentuk kegiatan pelayanan kepada umum yang dilaksanakan oleh 
instansi pemerintah di pusat, didaerah dan dilingkungan Badan Usaha Milik Negara atau Daerah (BUMN/BUMD) dalam bentuk barang atau jasa dalam upaya pemenuhan kebutuhan masyarakat maupun dalam rangka pelaksanaan ketentuan peraturan perundang-undangan.

Beberapa pengertian dasar yang di tuliskan di dalam keputusan menteri pendayagunaan aparatur Negara No.63 tahun 2003 adalah sebagai berikut: 1. Pelayanan publik adalah segala kegiatan pelayanan yang dilaksanan oleh penyelenggara pelayanan publik sesuai upaya pemenuhan kebutuhan penerima pelayanan maupun pelaksanaan ketentuan peraturan perundangundangan. 2. Penyelenggara pelayanan publik adalah instansi pemerintah. 3. Instansi pemerintah adalah sebutan kolektif meliputi satuan kerja/satuan organisasi kementerian, departemen, lembaga pemerintah non depertemen, kesektariatan lembaga tertinggi dan tinggi negara dan instansi pemeriintah lainnya, baik pusat maupun daerah termasuk badan usaha milik negara, badan hukum milik negara dan badan usaha milik daerah. 4. Unit penyelenggara pelayanan publik adalah unit kerja pada instansi pemerintah secara langsung memberikan pelayanan kepada penerima pelayanan publik. 5. Pemberi Pelayanan publik adalah pejabat/pegawai instansi pemerintah yang melaksanakan tugas dan fungsi pelayanan publik sesuai dengan peraturan perundang-undangan. 6 . Pemerintah pelayanan publik adalah orang, masyarakat, instansi pemerintah dan badan hukum. 7. Biaya pelayanan publik adalah segala biaya sebagai imbal jasa atas pemberian pelayanan publik yang besaran dan tata cara pembayaran di tetapkan oleh pejabat yang berwenang sesuai ketentuan peraturan perundang-undangan. 8 . Indeks kepuasan masyarakat adalah tingkat kepuasan masyarakat dalam memperoleh pelayanan yang diperoleh dari penyelenggara atau pemberi pelayanan sesuai harapan dan kebutuhan masyarakat.

Pelayanan adalah suatu kegiatan atau urusan kegiatan yang terjadi dalam interaksi langsung antara seseorang dengan orang lain atau 
mesin secara fisik dan menyediakan kepuasan pelanggan.

Menurut Pasolog (2010:128) Pelayanan pada dasarnya dapat di definisikan sebagai aktifitas seseorang,kelompok atau organisasi baik langsung maupun tidak langsung untuk memenuhi kebutuhan. Pelayanan publik adalah sebagai setiap kegiatan yang di lakukan oleh pemerintah terhadap sejumlah manusia yang memiliki setiap kegiatan yang menguntungkan dalam hasilnya tidak terikat pada suatu produk secara fisik.

Berdasarkan berbagai pendapat di atas, penulis dapat menyimpulkan bahwa pelayan publik adalah aktivitas atau kegiatan pemberian layanan yang di lakukan oleh suatu organisasi dalam upaya pemenuhan masyarakat dalam rangka mencapai tujuan tertentu yaitu kesejahteraan masyarakat. Jaminan sosial adalah perlindungan yang diberikan oleh masyarakat bagi anggota-anggotanya untuk resiko-resiko atau peristiwaperistiwa tertentu dengan tujuan, sejauh mungkin, untuk menghindari peristiwa-peristiwa tersebut yang dapat mengakibatkan hilangnya atau turunya sebagian besar penghasilan, dan untuk memberikan pelayanan medis dan/atau jaminan keuangan terhadap konsekuensi ekonomi dari terjadinya peristiwa tersebut, serta jaminan untuk tunjangan keluarga dan anak. Secara singkat jaminan sosial diartikan sebagai bentuk perlindungan sosial yang menjamin seluruh rakyat agar dapat mendapatkan kebutuhan dasar yang layak.

Ciri - ciri layanan publik yang baik adalah memiliki unsurunsur sebagai berikut (Kasmir, 2006:34): a. Tersedianya karyawan yang baik, b.Tersedianya sarana dan prasarana yang baik, c. Bertanggung jawab kepada setiap nasabah (pelanggan) sejak awal hingga akhir, d. Mampu melayani secara cepat dan tepat, e. Mampu berkomunikasi, f. Memberikan jaminan kerahasiaan setiap transaksi, g. Memiliki pengetahuan dan kemampuan yang baik, h. Berusaha memahami kebutuhan nasabah (pelanggan), i. Mampu memberikan kepercayaan kepada nasabah (pelanggan).

\section{METODE PENELITIAN}

Penelitian ini dilakukan selama 2 (dua bulan) mulai tanggal 
25 Agustus sampai bertempat 25 Oktober 2016 di RSUD Syech Yusuf Kabupaten Gowa. Adapun alasan pemilihan lokasi disebabkan karena di RSUD Syech Yusuf Kabupaten Gowa merupakan salah satu Rumah sakit Umum Daerah yang ada di Kabupaten Gowa yang menjalankan program BPJS di rancang untuk memperoleh manfaat pemeliharaan kesehatan dan perlindungan dalam memenuhi kebutuhan dasar kesehatannya.

Jenis penelitian ini adalah deskriptif kualitatif dengan tipe penelitian fenomenologi untuk memberikan gambaran secara jelas berdasarkan masalah yang diteliti.

Data bersumber dari data primer dan sekunder. Dengan Informan berjumlah delapan orang. Tehnik pengumpulan data di lakukan dengan tiga cara yaitu: (1) Observasi; (2) wawancara; (3) dokumentasi dan data dianalisis berdasarkan tiga komponen menurut Miles dan Huberman (dalam Sugiyono 2014: 92-99) yaitu: (1) reduksi data, (2) penyajian data, (3) Verifikasi atau penarikan kesimpulan.

\section{HASIL DAN PEMBAHASAN}

Manajemen pelayanan adalah proses penerapan ilmu dan seni untuk menyusun rencana, mengkoordinasikan dan menyelesaikan aktivitas-aktivitas pelayanan demi tercapainya tujuantujuan pelayanan. Sasaran Manajemen Pelayanan adalah kepuasan pelanggan. Dalam menyelenggarakan pelayanan baik kepada pelanggan internal maupun external, pihak penyedia dan pemberi layanan harus selalu berupaya untuk mengacu kepada tujuan utama pelayanan yaitu kepuasan konsumen atau kepuasan pelanggan. Adapun fungsi-fungsi manjemen dalam manajemen pelayanan bagi peserta BPJS Kesehatan di RSUD Kabupaten Gowa yang menjadi pembahasan dalam bab ini adalah fungsi perencanaan, fungsi pelaksanaan dan fungsi pengawasan.

Tiga konsep dalam memberikan pelayanan di RSUD Syech Yusuf yaitu input, proses dan output. Input pelayanan yaitu bagaimana RSUD menyediakan sarana dan prasarana, memenuhi ketersediaan tenaga medis, bidan dan tenaga medis lainnya. Proses layanan merupakancara rumah sakit memberikan pelayanan sesuai dengan standar yang ditetapkan. 
Output pelayanan adalah bagaimana standar pelayanan minimal rumah sakit itu tercapai. Untuk memenuhi ketiga konsep dalam memberikan pelayanan di RSUD, pihak rumah sakit tersebut melaksanakan akreditasi rumah sakit.

Pihak rumah sakit memiliki tiga konsep untuk memberikan pelayanan kepada pasien. Agar mendapat pelayanan sesuai dengan apa yang dibutuhkannya. Pelayanan adalah suatu kegiatan atau urusan kegiatan yang terjadi dalam interaksi langsung antara seseorang dengan orang lain atau mesin secara fisik dan menyediakan kepuasan pelanggan. Berdasarkan pengertian diatas maka dapat di simpulkan bahwa pelayanan merupakan suatu bentuk sistem, prosedur atau metode tertentu di berikan kepada orang lain. Dalam hal ini, kebutuhan pelanggan tersebut dapat terpenuhi sesuai dengan harapan atau keinginan pelanggan dengan tingkat pesepsi mereka.

Pelayanan publik yang di kelola oleh pemerintah pada dasrnya dapat di kelompokkan menjadi tiga kelompok besar, pelayanan umum yaitu pelayanan yang diberikan sesuai dengan tugas pokok dan fungsi utama yangdi berikan kepada organisasi atau unit pelayanan yang bersangkutan. Pelayanan fasilitas yakni pelayanan yang diberikan untuk menunjang pelayanan utama, yang jika pelayanan fasilitas ini tidak dilakuukan maka pelayanan utama tidak dapat berjalan dengan baik. Pelayanan pendukung adalah pelayanan tambahan yang berfungsi untuk menambah nilai/kualitas pelayanan utama yang diberikan atau untuk membedakan pelayanan utama yang diberikan dengan pelayanan yang sama yang disediakan oleh organisasi lain.

Persiapan/kesiapan adalah tindakan yang dilakukan oleh pihak RSUD Syech Yusuf Kabupaten Gowa dalam menyediakan petugas kesehatan yang berkompeten dibidangnya. kesiapan sumber daya yang dimiliki RSUD Syech Yusuf Kabupaten Gowa. Dalam memberikan pelayanan terbaik kepada pasien. Untuk itu seluruh petugas yang melayani pasien baik dokter, perawat dan bidan semuanya memiliki STR dan Surat izin praktek. 
Pelayananan pihak rumah sakit memiliki sumber daya seperti dokter, perawat dan bidan yang dilengkapi dengan STR dan surat izin praktek. Dari para informan tersebut diperoleh informasi tentang persiapan/kesiapan dalam memberikan pelayanan oleh pihak rumah sakit untuk memberikan pelayanan terbaik kepada pasien atau peserta BPJS Kesehatan.

Perencanaan adalah salah satu aktifitas manajerial yang berperan penting dalam menentukan efektifitas suatu kegiatan teramasuk kegiatan pelayanan. Melalui perencanaan kita dapat mengetahui apa yang hendak dicapai, cara untuk meraihnya, dan siapa yang bertanggungjawab untuk mencapai tujuan yang telah ditentukan bersama. Perencanaan memiliki 2 dimensi yaitu sasaran dan rencana.

Sasaran adalah tujuan atauhasil yang akan dicapai oleh organisasi sementara rencana adalah dokumen yang membuat cara dan strategi mencapai sasaran.

Misi dan strategi (perencanaan) pihak rumah sakit tersebut untuk memberikan pelayanan yang baik kepada pasien atau peserta BPJS Kesehatan yaitu mewujudkan standar pelayanan minimum rumah sakit, kepuasan pasien/keluarga pasien, menyediakan sarana dan prasarana, pemenuhan ketersediaan tenaga medis, memberikan pelayanan sesuai standar yang telah ditetapkan. Dalam mewujudkan rencana tersebut pihak rumah sakit berupaya menyediakan fasilitas penunjang operasional pelayanan medis, dan juga menjamin tenaga kesehatan yang melayani pasien telah memiliki bukti legalitas praktek dan berkompeten di bidangnya.

Unit penyelenggara pelayanan publik adalah unit kerja pada instansi pemerintah secara langsung memberikan pelayanan kepada penerima pelayanan publik. Pemberi Pelayanan publik adalah pejabat/pegawai instansi pemerintah yang melaksanakan tugas dan fungsi pelayanan publik sesuai dengan peraturan perundang-undangan. Pemerintah pelayanan publik adalah orang, masyarakat, instansi pemerintah dan badan hukum. Biaya pelayanan publik adalah segala biaya 
sebagai imbal jasa atas pemberian pelayanan publik yang besaran dan tata cara pembayaran di tetapkan oleh pejabat yang berwenang sesuai ketentuan peraturan perundangundangan. Indeks kepuasan masyarakat adalah tingkat kepuasan masyarakat dalam memperoleh pelayanan yang diperoleh dari penyelenggara atau pemberi pelayanan sesuai harapan dan kebutuhan masyarakat.

Pelaksanaan adalah proses dalam menjalankan rencana yang telah ditetapkan sebelumnya. Pelaksanaan merupakan usaha menggerakkan anggota-anggota kelompok sedemikian rupa, hingga mereka berkeinginan dan berusaha untuk mencapai tujuan yang telah direncanakan bersama. Indikator dari rencana yang telah benar-benar direalisasikan yaitu output dari pelaksanaan tersebut. Output yang dimaksud adalah tercapainya tujuan yang diinginkan, setidaknya mendekati pada tujuan tersebut.

Pihak rumah sakit telah memberikan playanan ketiga konsep yang ada dan sesuai standar kemampuannya.

Mereka berpendapaat bahwa pelayanan yang mereka berikan sudah cukup memuaskan. Tetapi disisi lain diapun berpendapat bahwasanya pelayanan perlu ditingkatkan lagi agar supaya pelayanannya lebih berkualitas . Pelayanan yang di berikan pihak rumah sakit sudah cukup baik dan pelayanan yang didapatkan sudah sesuai dengan standar pelayanan.

Pelayanan yang di berikan dari dulu hingga saat ini tidak ada yang berubah. Pelayanan yang diberikan sudah sesuai dengan prosedur yang ada, akan tetapi disisi lain masih ada perawat yang cuek dengan pasien. Di saat mereka membutuhkan pelayanan perawat yang seharusnya melayani pasien seakan-akan sok sibuk mengerjakan sesuatu dan mengabaikan pasien yang membutuhkan pelayanannya.

Pelaksanaan adalah suatu tindakan untuk mengusahakan agar semua anggota kelompok berusaha untuk mencapai sasaran yang sesuai dengan perencanaan manejerial dan usaha-usaha organisasi. Jadi pelaksanaan artinya menggerakkan orang-orang agar mau bekerja dengan sendirinya atau dengan 
kesadaran secara bersama-sama untuk mencapai tujuan dikehendaki secara efektif, dalam hal ini yang dibutuhkan adalah kepemimpinan. Untuk melaksanakan secara fisik kegiatan dari aktivitas tesebut, maka manajer mengambil tindakantindakannya kearah itu.

Pasien merasa jenuh dengan pelayanan yang rumah sakit berikan. Mereka berpendapat bahwa pihak rumah sakit membedakan jika salah satu pasien memiliki keluarga salah satu perawat disana. Keluhan yang di sampaikan hampir sama dengan informan sebelumnya. Kurangnya fasilitas kamar yang ada di rumah sakit membuat pasien merasa lambat dilayani. Karena pihak rumah sakit bingung harus memindahkan pasien kemana lagi. Untuk itu pihak rumah sakit harus menambah fasilitas kamarnya.

\section{Tempat Penerimaan Pasien} Rawat Jalan (TP2RJ) Pasien BPJS Kesehatan biasanya dilayani belakangan untuk pengambilan rekam medis. Hal itu dikarenakan pegawai yang menangani rekam medis pasien peserta BPJS sering datang terlambat. Padahal, jam pelayanan dimulai pukul delapan pagi. Sikap apatis sebagian petugas di ruang tersebut membuat sebagian pasien kebingungan dengan prosedur pelayanan di rumah Sakit.

Tujuan utama RSUD Syech Yusuf Gowa adalah memberikan pelayanan terbaik kepada pasien tanpa terkecuali dan memenuhi standar minimum pelayanan dengan melaksanakan kebijakan atau strategi yang ditetapkan sebelumnya. Namun yang terjadi umumnya adalah ketidakpuasan pasien terhadap pelayanan di rumah sakit tersebut utamanya dari pasien peserta BPJS Kesehatan. Jika merujuk pada perencanaan yang ada, RSUD Syech Yusuf Gowa belum maksimal dalam memberikan pelayanan, yakni baru memenuhi input pelayanan seperti ketersediaan sarana dan prasarana, ketersediaan tenaga medis perawat, medan, bidan, dll.

Berdasarkan kesaksian penulis selama melakukan observasi langsung di rumah sakit, di setiap ruang tindakan baik di IGD, ICU, ruang persalinan, dan kamar perawatan, ruang opersasi, dan lainlain tersedia panduan praktek dan 
prosedur kerja atau tindakan. Selebihnya, konsep tersebut belum tampak dijalankan dengan baik, utamanya dalam memberikan kepuasan terhadap pasien. Masih banyak pasien atau peserta BPJS yang mengeluh dengan pelayanan yang mereka terima selama berobat di rumah sakit tersebut. Sedangkan untuk monitoring dan evaluasi terhadap kegiatan pelayanan kesehatan dan kepuasan pelanggan masih perlu perhatian serius dalam pelaksanaannya karena menurut asumsi penulis jika kegiatan monev dijalankan dengan baik oleh pihak yang berwenang tentunya masalah ketidakpuasan pasien atau peserta BPJS Kesehatan akan bisa diminimalisir dari tahun ke tahun.

Setiap pasien baik itu pasien dengan BPJS Kesehatan berhak mendapatkan pelayanan kesehatan terbaik dari rumah sakit. Dalam kalimat lain kepuasan pasien dan keluarga pasien menjadi hal yang utama dalam pelayanan. Namun yang harus diingat adalah untuk mendapatkan pelayanan yang terbaik pasien harus memenuhi kewajibannya baru mendapatkan haknya. Jadi dalam pelayanan juga membutuhkan kerjasama yang baik dari pasien dan keluarga pasien. Pihak rumah sakit wajib memastikan bahwa pasiennya dan keluarga pasiennya sudah mengerti hak dan kewajiban yang harus dipenuhi sebelum menerima pelayanan agar pelayanan dapat berjalan dengan baik. Selama melakukan pengamatan di RSUD Syech Yusuf Gowa, penulis menyaksikan sebagian besar pasien belum mengerti persyaratan administrasi yang harus dilengkapi pada saat melakukan permohonan pelayanan di ruang Tempat Penerimaan Pasien Rawat Jalan (TP2RJ). Hal inilah yang menjadi salah satu penyebab lambatnya pelayanan di rumah sakit ini. Ditambah lagi sikap sebagian petugas yang apatis yang tidak begitu mempedulikan keluhan atau pertanyaan para pasien.

Penelitian menunjukkan pelaksanaan pelayanan rumah sakit baru belum terlaksana dengan baik. Strategi pelayanan yang sudah terlaksana yaitu tersedianya sarana dan prasarana, terpenuhinya tenaga medis yang berkompeten dan 
memiliki bukti legalitas praktek, tersedianya pedoman praktek klinik dan prosedur tindakan, tercapainya standar pelayanan minimal rumah sakit, dan terlaksananya pelayanan sesuai standar. Adapun konsep pelayanan kesehatan yang masih butuh perhatian serius dari pihak rumah sakit untuk dilaksanakan yaitu kepuasan pasien dan keluarga pasien, indikator kinerja, dan yang lebih utama adalah soal monitoring dan evaluasi kegiatan pelayanan dan kepuasan pasien.

Pengawasan adalah proses dari pelaksanaan yang sedang dilakukan sesuai dengan rencana yang telah di tentukan sebelumnya. Pengawasan adalah penemuan dan penerapan cara dan alat untuk menjamin bahwa rencana telah di laksanakan sesuai dengan rencana yang telah di tetapkan.

Standar pelayanan perlu secara terus menerus dimonitor dalam pelaksanaannya. Monitoring tidak hanya berkaitan dengan sejauh mana pelayanan telah memenuhi standar yang telah ditetapkan, tetapi juga konsistensi bahkan upaya peningkatan dalam menghasilkan pelayanan yang baik. Jika dalam proses monitoring ditemukan/diperoleh penyimpangan, maka hendaknya dengan cepat, pihak penyedian pelayanan publik melakukan tindakan-tindakan pengendalian agar proses dan pelaksanaan pelayanan tetap dapat menghasilkan pelayanan yang sesuai dengan standar yang telah ditetapkan/disepakati. Dengan monitoring, dapat juga diprediksi berbagai permasalahan/persoalan yang mungkin muncul, sehingga perlu dilakukan upaya-upaya agar tatalaksana pelayanan publik tetap dapat berjalan dengan sebaikbaiknya atau setidaknya mempersiapkan berbagai tindakan jaga-jaga, jika hal-hal yang kurang menguntungkan dapat saja terjadi.

Penilaian pekerjaan adalah sistem yang digunakan dalam menilai pekerjaan yang dilaksanakan oleh phak RSUD Syech Yusuf Kabupaten Gowa. RSUD melakukan pengawasan terhadap kinerja pegawainya, namun fakta dilapangan kinerja pegawai RSUD dalam melayani pasien kurang baik. Dilihat dari pegawai yang cuek, lambat 
dalam melayani pasien ditambah persediaan obat di rumah sakit kosong, jadi pasien harus membeli obat di apotik yang berada diluar rumah sakit.

Pihak rumah sakit harus lebih meningkatkan kinerja pegawainya. Pelayanan yang diberikan harus cepat demi mendapatkan kepuasan terhadap pelayanan di rumah sakit. Melihat apa yang terjadi di lapangan masih banyak perawat yang tidak melakukan pelayanan dengan prosedur yang ada. Masih adanya sifat acuh tak acuh yang mereka berikan kepada pasien yang menyebabkan pasien merasa tidak nyaman dengan pelayanannya. Pasien berpendapat mereka ingin mendapatkan pelayanan yang terbaik dari pihak rumah sakit. Pihak rumah sakit belum melaksanakan pengawasannya dengan belum baik. Padahal mereka mempunyai standar pelayanan yang harus dicapai demi terciptanya pelayanan yang maksimal.

Tempat Penerimaan Pasien Rawat Inap (TP2RI) pasien yang dirawat di layani dengan apa adanya. Mereka kadang mendapat pelayanan dengan perawat yang cuek seakanakan sibuk dengan alat komunikasinya masing-masing. Begitu juga dengan sebagian perawat yang biasanya kadang datang terlambat. Mereka tidak berfikir punya tanggung jawab untuk membuat pasien merasa nyaman saat dia dirawat. Padahal diketahui tujuan utama dari rumah sakit adalah memberikan pelayanan yang terbaik kepada pasien tanpa terkecuali.

Tindakan perbaikan adalah pekerjaan yang dikerjakan sesuai dengan apa yang direncanakan pihak RSUD Syech Yusuf Kabupaten Gowa. Tindakan sangat penting untuk dilakukan oleh pihak rumah sakit melihat masih banyak yang harus dibenahi termasuk pada memberikan pelayannya kepada pasien. Setiap apa yang telah dilakukan itu salah maka mereka segera harus bertanggung jawab menerima konsekuensi yang telah disepakati apabila telah melakukan kesalahan. Agar tidak akan terjadi lagi kesalahan yang sama sebelumnya.

Tindakan perbaikan pelayanan yang harus diperhatikan oleh pihak 
rumah sakit apabila seorang mewujudkan standar pelayanan pegawai/perawat melakukan minimum, kepuasan pasien, penyimpangan. Perawat/pegawai harus menyediakan sarana dan prasarana, sigap dalam melayani pasien. Pihak pemenuhan ketersediaan tenaga rumah sakit harus melakukan tindakan perbaikan jika terjadi penyimpangan, supaya dapat menjalankan pelayanan sesuai tujuan utama dari rumah sakit itu sendiri. Dengan dilakukannya tindakan perbaikan agar supaya pihak penyedia pelayanan melakukan tindakan-tindakan pengendalian agar proses dan pelaksanaan pelayanan tetap dapat menghasilkan pelayanan yang sesuai dengan apa yang telah ditetapkan atau disepakati sebelumnya.

\section{KESIMPULAN}

Konsep adalah proses atau cara pihak RSUD Syech Yusuf Kabupaten Gowa merancang untuk memberikan pelayanan kesehatan kepada mereka yang membutuhkan. Ada tiga konsep yang diberikan dalam memberikan pelayanan yang pertama input pelayanan, proses pelayanan dan output pelayanan. Misi dan strategi pihak rumah sakit untuk memberikan pelayanan yang baik kepada pasien yaitu medis dan memberikan pelayanan sesuai standar yang telah ditetapkan.

Persiapan/kesiapan adalah tindakan yang dilakukan oleh pihak RSUD Syech Yusuf Kabupaten Gowa dalam menyediakan petugas kesehatan yang berkompeten dibidangnya. Dalam mewujudkan hal tersebut pihak rumah sakit berupaya menyediakan fasilitas penunjang operasional pelayanan medis dan juga menjamin tenaga kesehatan yang melayani pasien telah memiliki bukti legalitas praktek .

Pelayanan yang baik akan memberikan dampak yang baik pula. Pelanggan diibaratkan raja dan pelayanan yang baik wajib dilakukan oleh pihak RSUD Syech Yusuf Kabupaten Gowa. Pihak RSUD Syech Yusuf Kabupaten Gowa telah memberikan pelayanan sesuai ketiga konsep yang ada dan sesuai standar kemampuannya. Mereka juga berpendapat bahwa pelayanan yang mereka berikan sudah cukup memuaskan bagi pasien. 


\begin{abstract}
Penilaian pekerjaan adalah sistem yang digunakan dalam menilai pekerjaan yang dilaksanakan oleh phak RSUD Syech Yusuf Kabupaten Gowa. Penilaian dalam hal memberikan pelayanan kepada pasien masih kurang ini dilihat masih banyak perawat yang sering datang terlambat. Mereka tidak berfikir punya tanggung jawab untuk memberikan pelayanan terbaik
\end{abstract} kepada pasien dengan tujuan utama rumah sakit.

Tindakan perbaikan adalah pekerjaan yang dikerjakan sesuai dengan apa yang direncanakan pihak RSUD Syech Yusuf Kabupaten Gowa. Dengan dilakukannya tindakan perbaikan agar supaya pihak penyedia pelayanan melakukan tindakan-tindakan pengendalian agar proses dan pelaksanaan pelayanan tetap dapat menghasilkan pelayanan yang sesui dengan apa yang telah ditetapkan atau disepakati sebelumnya.

\section{Daftar Pustaka}

Anton Mulyono Aziz, dan Maya Irjayanti. 2014. Manajemen. Bandung: Mardika Group.
Ibrahim, Amin. 2008. Teori dan Konsep Pelayanan Publik serta Implementasinya. Bandung: Mandar Maju.

Irham, Fahmi. 2011. Manajemen Teori, Kakus dan Solusi. Bandung: ALFABETA.

Kasmir. 2006. Kewirausahaan. Jakarta: Rajawali Pers

Moenir, AS. 2002. Manajemen Pelayanan Umum di Indonesia. Jakarta : Bumi Aksara.

Pasolong, Harbani. 2010. Teori Administrasi Publik. Bandung: Alfabeta.

Sulastri, Lilis. 2014. Manajemen Sebuah Pengantar Sejarah, Tokoh, Teori dan Praktik. Bandung: La Goods Publishing.

Solihin, Ismail. 2010. Pengantar Manajemen. Jakarta: Erlangga.

Terry, George. 2010. Dasar-Dasar Manajemen. Jakarta: Bumi Aksara.

Ulber, Silalahi. 2011. Asas-Asas Manajemen. Bandung: PT. RefikaAditya 